4th Global Business Research Congress, May 24-25, 2018, Istanbul, Turkey.

\title{
MEASURING THE READINESS LEVEL OF LOGISTICS COMPANIES TO INDUSTRY 4.0
}

\author{
DOI: 10.17261/Pressacademia.2018.903 \\ PAP- V.7-2018(56)-p.303-305
}

\section{Melis Gizem Ozturk ${ }^{1}$, Ahmet Murat Koseoglu²}

${ }^{1}$ Okan University, Tepeören Mahallesi, Okan Üniversitesi Tuzla Kampüsü, 34959 Tuzla, Istanbul, Turkey. melis.ozturk@okan.edu.tr, ORCID: 0000-0001-7927-8467

${ }^{2}$ Okan University, Tepeören Mahallesi, Okan Üniversitesi Tuzla Kampüsü, 34959 Tuzla, Istanbul, Turkey. murat.koseoglu@okan.edu.tr, ORCID: 0000-0002-0656-2798

To cite this document

Ozturk, M. G., Koseoglu, A. M. (2018). Measuring the readiness level of logistics companies to industry 4.0. PressAcademia Procedia (PAP), V.7, p.303-305

Permemant link to this document: http://doi.org/10.17261/Pressacademia.2018.903

Copyright: Published by PressAcademia and limited licenced re-use rights only.

\begin{abstract}
Purpose- Aim of the study is to determine readiness level of logistics companies to industry 4.0 to provide insights companies regarding which types of actions should be taken to achieve customer satisfaction and expectations. Industry 4.0 is a new concept that is still in development phase, and readiness level of the companies will be an indicator of the survival of logistics companies in the changing environment.

Methodology- Indepth interviews conducted with logistics companies in a specific work environment to compare and contrast companies that are affecting from similar variables in the industry.

Findings- Readiness levels of companies change according to customer bases, the vision of the company, scope of the company and some other variables.

Conclusion- Logistics companies a different level of readiness regarding Industry 4.0 and measuring this levels offers insights fort he companies and guide them which measures they should take to achieve the higher level of integration.
\end{abstract}

Keywords: Industry 4.0, industrial revolution, logistics, logistics 4.0.

JEL Codes: L90, L91

\section{INTRODUCTION}

Logistics is a system that shapes according to demand changes that comes from customers. As a result of this logistics are now facing a new challenge that will come with new industrial revolution, Industry 4.0. The difference of Industry 4.0 from other industrial revolutions, Industry 4.0 does not result in a new invention but a result of a new innovative approach. Reason for this innovative approach is the fact that world will not be enough for humans shortly and this will lead to problems in businesses. However, with the automation and other features of Industry 4.0, this problem can be solved.

As an essential service, logistics will get affected by every single change in the businesses because they aim to provide right products to right customers at the right time. Therefore, logistic companies should respond every change in the industry. To answer changes in the business, logistics companies should review their information and communication technologies (ICT).

ICT is a relatively new topic for the logistics companies, but it already becomes an essential part of logistics providers because their customers want continuous information about their products. Industry 4.0 is mainly about technology; therefore, it is inevitable for logistics companies to shape their ICT systems according to new aspects of Industry 4.0.

\section{INDUSTRY 4.0}

Industry 4.0 is the vision of the German government that arised in 2011 that is focusing on technological developments in manufacturing and other business processes. Industry 4.0 consists of three main factors, the Internet of objects, the Internet of services and the cyber physical systems at the beginning. The Internet of Things is the provision of communication and interaction of physical objects with each other through various technological methods. The concept first introduced by Kevin Ashton in 1999 was developed from first point of arrival to today's position. The main advantage of the internet of objects is to reduce the human factor by means of communication protocols and to enable the devices to communicate with each other through intelligent networks. Through this communication network, problems that may arise as a result of problems experienced by objects are prevented, information sharing and efficiency increase as a result of interactions. While 11 billion devices in 2011 were connected to the internete 50 billion devices in 2020 are expected to be connected to the internete, this prediction shows that the percentage of non-connected objects in the future will be extremely low. 
The internet of the services is similar to the internet of the objects and explains that the services are connected to the internet. Nowadays, companies are paying attention to the profits they earn from after-sales services as well as the profits they earn from the products they sell. For example, today, Rolls Royce is creating a major source of revenue by selling engine maintenance on flight time instead of selling engines to aircraft companies. It is a service for a party to buy things that are tangible, such as expertise, counseling and information, for another partisan paycheck. In this case, it can be predicted that the innovative approaches of the internet with the objects will bring additional profit to the firm.

Cyber-physical systems act as a bridge between the real world and the virtual world. As a result of globalization, the necessity of accessing information at any moment will reach a different dimension with cyber-physical systems. Future simulations for Firms will be even more effective with cyber-physical systems. Cyber-Physical Systems play an essential role not only in production but in many places. Some of them are listed as follows:

- Physical and organizational or business processes monitor and control

- Includes significant user interaction / interaction

- Real-time configuration, deployment or commissioning and adaptation to the reactive changes in the environment

- Continually monitors and optimizes its performance

- High reliability

- $\quad$ Requires different technical disciplines and integration of different application areas

- Qualification at the local, regional, national and global level requires high-level hierarchical decision-making systems. (Ghafory, 2017)

Currently Industry 4.0 has main features automation, data collection and exchange, cloud systems, cyber-physical systems (CPS), robots, big Data, artificial intelligence (Al), loT and loS, and, autonomy.

\section{INDUSTRY 4.0 AND LOGISTICS}

Industry 4.0 will change almost every aspect of business including logistics activities. In logistsics main changes will be on resource planning, warehouse management systems, transportation management systems, intelligent transportation systems, information security.

Resource planning will be based on CPS because CPS's features are based on improving flexibility, productivity and agility. Therefore, simulations based on showing how to plan resources will be changed trough more clear estimations about people, sources, and equipments.

Especially, the introduction of 'smart' management throughout the proper adoption and implementation of Warehouse

Management Systems (WMS) which will transform the warehouse activities into the future requirements of the

inbound logistics according to the Industry 4.0 paradigm

Especially, the introduction of 'smart' management throughout the proper adoption and implementation of Warehouse Management Systems (WMS) which will transform the warehouse activities into the future requirements of the inbound logistics according to the Industry 4.0 paradigm (Barreto, Amaral, Pereira, 2017). WMS will be more autonomous and less dependent on human factor. It will increase efficiency of warehouse activities because in current systems WMS is based on humans and it increases possibility of mistake.

Transportation management system controls communication between order management systems and distribution center. Therefore, it is a crucial part of logistic activities. With industry 4.0, real time information flow will be more important and it will lead to intelligent transportation systems. Intelligent Transportation System (ITS) is a novel field that interoperates in different fields of transportation systems such as transportation management, control, infrastructure, operations, policies and control methods. ITS adopts new technologies like computing hardware, positioning system, sensor technologies, telecommunications, data processing, virtual operation and planning techniques (Barreto, Amaral, Pereira, 2017)

\section{METHODOLOGY}

In the first step, facts are established and accepted as truths and used these facts to provide a foundation for the framework. These accepted facts are definition of industry 4.0 and relation of industry 4.0 and logistics. According to literature review we define industry 4.0 as " digital transformation of the value chain of the industry" and relationship between industry 4.0 and logistics as "changes in resource planning, warehouse management systems, transportation management systems, intelligent transportation systems, and information security."

In the second step, indepth interviews are conducted with two logistics companies that are currently focusing on Industry 4.0 applications. While doing indepth interviews, semi structured questions were asked and interviewees were managers that are directly responsible from the industry 4.0 applications in the company. One of the companies were 3PL company and the other one is $4 \mathrm{PL}$ company. Both companies are acting as pioneers for Turkish logistics sector in terms of industry 4.0 applications.

\section{CONCLUSIONS}

As a result of this study, we gained insights about current situation and we noticed a pattern of changes in the supply and demand. Suppliers and customers are giving more importance to information flow than ever and in order to satisfy this logistics companies are focusing on this aspect of business. There will be major changes in resource planning, warehouse management systems, transportation management systems, intelligent transportation systems, information security. In resource planning, more flexible approaches will be used. 
WMS will be less and less dependent on human factors and technological advancements will be used. In this process logistics companies will act as planners and providers.

\section{REFERENCES}

Acar, Z., Köseoğlu, M. (2014). Lojistik yaklaşımıyla tedarik zinciri yönetimi. Nobel Yayıncılık, $1^{\text {st }}$ Edition, Ankara.

Barreto, L., Amaral, A., Pereira, T. (2017). Industry 4.0 implications in logistics: an overview. Procedia Manufacturing, 13, $1245-1252$. doi:10.1016/j.promfg.2017.09.045

Ghafory, I. (2017). Siber fiziksel sistemler. http://www.endustri40.com/siber-fiziksel-sistemler/, (Access Date:06.06.2018).

Hofmann, E., Rüsch, M. (2017). Industry 4.0 and the current status as well as future prospects on logistics. Computers in Industry, 89 , 2334

Müller, J., Dotzauer, V., Voigt, K. I. (2017). Industry 4.0 and its impact on reshoring decisions of German manufacturing enterprises. In Supply Management Research (pp. 165-179). Springer Gabler, Wiesbaden.

Lee, J., Bagheri, B., Kao, H. A. (2015). A cyber-physical systems architecture for industry 4.0-based manufacturing systems. Manufacturing Letters, 3, 18-23.

Rüßmann, M., Lorenz, M., Gerbert, P., Waldner, M., Justus, J., Engel, P., Harnisch, M. (2015). Industry 4.0: The future of productivity and growth in manufacturing industries. Boston Consulting Group, 9. 